\title{
On Harmonious Relationship of the Instrumental and Humanistic Values of College English Based on Humanism*
}

\author{
WANG Li \\ Qingdao University of Science and Technology, Qingdao, China
}

\begin{abstract}
This paper discusses the scientific view of college English teaching reform based on humanism which has a great influence on college English teaching. We should assess the reform over the past decade in an objective way and understand the harmonious relationship of the instrumental and humanistic values of college English by reforming the curriculum structure, teaching materials, and teaching design and assessment.
\end{abstract}

Keywords: humanism, instrumental value, humanistic value, college English teaching

\section{Introduction}

College English teaching in China has an obvious tendency to focus on exam-oriented education because of being influenced by pragmatism and utilitarianism for a long time; as a result, it is common to emphasize the skills at college while neglecting humanity. Humanism is always ignored when designing college English curriculum and teaching practice. As a matter of fact, as a compulsory course, college English should not only reflect its instrumental values, but also exert its humanistic values.

This paper discusses the scientific view of college English teaching reform based on humanism and puts forward that the harmonious relationship of the instrumental and humanistic values is the principle of college English currently. In addition, this paper suggests how to exert the humanism of college English course in order to improve college English teaching.

In China, the harmonious relationship of the instrumental and humanistic values of college English teaching has been recognized by more and more scholars and teachers. Professor WANG Shou-ren, the chairman of higher school university foreign language education committee pointed out that college English teaching should contain both instrumental values and humanistic values, serving for the students' individual development in 2013. He mentioned the cultural factor in College English Course Teaching Requirements and held that college English course is not only a basic course for language, but also a quality-oriented course to extend knowledge and know the world culture with the instrumental values and humanistic values. College English teaching should focus on its humanistic values whether from the perspective of culturing the communicative ability or from the perspective of cultivating students by teaching. In addition, Professor ZHAO Hong-wei pointed out that various professionals

\footnotetext{
* Acknowledgements: This paper is the final result of the research project the author hosts "Harmonious Relationship of the Instrumental and Humanistic Values of College English Based on Humanism” that is supported by "National College Foreign Language Teaching Research Funds for Shanghai Foreign Language Education Press” in 2014. (Grant No. 2015SD0009-A). WANG Li, lecturer, master, Institute of Foreign Languages, Qingdao University of Science and Technology.
} 
with humanistic and national spirit who are good at English are needed in the face of the requirements of reform and opening policy. That is to say, the professionals are required to not only master the professional skills and communicative ability in English, but also get familiar with the cultural achievements obtained by both Chinese and foreigners from the ancient times to nowadays. Obviously, humanism is an important aspect of college English teaching which plays a significant role in cultivating the students' ability to learn on their own and improving their comprehensive culture quality.

In foreign countries, the humanistic values of language education was recognized and emphasized by the scholars many years ago. Maslow, an American psychologist constructed the psychological system based on humanism and redefined the meaning of motivation in Motivation and Personality. He thinks that human's motivation is the internal potential for a man to develop for the whole life since his birth. Rogers studied the learning process from the perspective of humanism with obvious tendency of humanism, emphasizing the subjective position of the learners. Richard put forward the non-language objective from the perspective of curriculum structure. He thinks that the curriculum structure should contain the related objectives if the language course tries to reflect the student-centered principle and multi-cultural idea. They are called non-language objectives because they are beyond the language knowledge.

\section{Both Instrumental and Humanistic Values Are the Requirements of College English Teaching}

As for the instrumental values, it is speculated by some people that most high-school students have mastered English as an instrument just according to the English ability equipped by part of the students who are good at English at international studies schools and key high schools. However, the real situation is that reading is usually centered while listening and speaking is often ignored because of the limitation of English class period at high schools and the restrict of the entrance exam to universities, thus most students belong to the beginners whether from what they have learned or from how they can apply to it. Even if the students have mastered enough vocabularies required by the entrance exam to universities, they still have great trouble in understanding the original version and getting the key points of speeches or lectures, let alone writing papers with high quality.

The students in the 21st century are bound to be equipped with good ability to mater English, which is decided by the national interest, social needs, and students' development. It is our duty to offer high-quality foreign language education for college students. Therefore, college English teaching needs to be strengthened and improved instead of being weakened. English knowledge learned at high schools is just simple language which suits the age and psychological characteristics of high-school students. But their English ability needs to be further improved after entering colleges. They should learn English knowledge that can reflect the characteristics of college education which is much more complicated than what they learned at high schools, like the abstraction of the text, the complexity of the grammatical structure, the richness of vocabularies, and so on.

However, when we offer the high-quality foreign language education to college students, we should not purely regard the language as an instrument. Language is the carrier of the culture as well as an important part of the culture. Hence, we should not ignore the humanistic values of English while focusing on its instrumental values. The humanistic values of high-school English teaching focuses on quality education, paying attention to 
the all-round development of human beings, penetrating the socialism core values system, and guiding the students to gradually form the right view of the world, the life, and the values. While the humanistic values of college English teaching should be different, focusing on the cultural self-consciousness. The Common European Framework of Reference for Languages (CEF) points out that one of the purposes of language teaching is to obtain the lifestyle, way of thinking, and life tradition in the foreign countries, helping to have a wider and deeper insight into the cultural heritage. In order to correspond to the requirements of China's development in a peaceful way and spread Chinese culture to the world, we need to know the world. In such a circumstance, learning foreign language is an effective way, helping to better know the outer world. College English teaching should help the students to broaden the international horizon and understand the western civilization, the way of thinking, and the life tradition, knowing how to treat the western culture and core values in a critic way, getting familiar with the difference between Chinese culture and the foreign countries', cultivating the ability to communicate with people from different culture, making the students know how to communicate in English efficiently. In the daily life, people will have difficulty in communicating if only mastering the language itself without knowing the difference between the ideology, social system, history and culture, life, and the way of thinking in the foreign countries and ours. College English teaching should not only pay attention to teach the culture and tradition in the west and the core values supported by the western culture, but also focus on knowing Chinese culture and how to introduce Chinese culture, together with the socialism with Chinese characteristics, the achievements brought by the reform and opening policy and Chinese society currently in a way that can be easier accepted by the west. The humanistic values of college English course should be shown by improving the soft power of Chinese culture and constructing our country to be a socialism culture power in order to better deal with the challenges brought by the communication between China and foreign countries.

It is a misunderstanding to strengthen the humanistic values of college English course by adding such lectures like British and American literature, British and American poetry, Shakespeare, and so on. The core of the humanistic values is centered on the human beings, advocating the values of the human beings and reflecting the respect to the human beings. As a public course for the art, the humanistic values of college English should be shown by spreading the positive power and promoting the healthy and comprehensive development of the human beings. Therefore, the instrumental values and the humanistic values of college English could be harmoniously combined instead of separating them.

\section{The Current Situation of College English Teaching: The Instrumental Value Is Emphasized While the Humanistic Value Is Ignored}

Under the influence of pragmatism and instrumentalism, there are some problems existing in our college English teaching. Firstly, there is an obvious tendency to be eager for quick success and instant benefit nowadays and the teaching is becoming more and more commercialized. In such a circumstance, the students just learn English by directly doing some exercises and reading some how-to books in order to better pass all kinds of tests because they consider English to be the way of finding a good job and going abroad. Once such goals are realized, the motivation to learn English will disappear, which is not helpful to the final success of foreign language learning. Secondly, college English teaching is merely limited to language knowledge and skills, leading the students to become those with narrow horizon and weak culture consciousness. College English teaching remains 
the surface structure of this language, like vocabularies and grammar under the effect of pragmatism, neglecting its bottom structure, like the thoughts and culture. It is common for the students to make the ridiculous mistakes because of neglecting the culture background of the language. Finally, the students' imagination and creativity are negatively influenced because college English teaching pays more attention to instill the knowledge and train the students mechanically. The traditional teacher-centered teaching mode pays attention to instill knowledge, thus dividing some texts with wise ideas into pure language grammar. The students are usually required to imitate and recite when learning language skills and doing exercises related to language itself after class, neglecting the students' ability to think critically and logically, thus hindering to develop their imagination and creativity, making the students lose the interest in English.

Generally speaking, it is easy to ignore the cultivation of the students' internal quality if only focusing on the instrumental values of college English teaching, which is harmful to the students to develop comprehensively. Such a tendency will hasten the students to go after pragmatism, which is against the objective of students' comprehensive development.

\section{The Harmonious Relationship of the Instrumental Values and the Humanistic Values Is Necessary for College English Teaching}

\section{Curriculum Structure}

Curriculum structure is the reflection of curriculum ideas. College English curriculum system of different colleges should be designed in accordance with the course requirements and the actual situation of different colleges. For example, college English course can be divided into compulsory course and optional course, or it can be classified into comprehensive English (like intensive reading), English skills (like listening, speaking, reading, and writing), English culture (like British and American literature), and professional English (like English the specific purpose) according to different contents. The compulsory course can construct the common basis of college English teaching, making sure that the students' English level can satisfy the general requirements of college English teaching. The optional course can further satisfy the students' requirements to develop individual personality. Such a course system focuses on the center position of the students, paying attention to the students' requirement to develop individual personality, which is beneficial to show the humanistic values of college English teaching.

\section{Teaching Materials}

Teaching materials are the basis of implementing the curriculum ideas. On one hand, we should reexamine and improve the original teaching materials, making it more suitable for the requirements of the new curriculum ideas. On the other hand, it needs plenty of teaching materials to open the optional course and it is necessary to edit a series of teaching materials suited for different colleges in order to satisfy the requirements of students' development for individual personality at different levels. The qualified colleges can organize the teachers to write the writing materials which directs at their own demand. Of course, the writing and issue of the teaching materials need the cooperation of English professionals, English teachers, and publishers. But one point that can be made sure of is that the humanistic values of college English teaching will become more plentiful with the richness of optional courses. 


\section{Teaching Design}

Teaching design is the key point of implementing the curriculum ideas. The teachers should change their teaching ideas, holding the principle of combining the humanism and the instrumentalism instead of only teaching language knowledge and skills. In addition to it, the teachers should know how to find and blend the humanistic information related with English-spoken nations, helping the students to be unconsciously influenced by the humanism. At the same time, the teachers should change the original teaching mode that is teacher-centered, guiding the students to know how to make good use of the modern technology, especially the multi-media device and cultivating the students' ability to learn on their own. Besides, the teachers can also help the students organize after-class activities related with English learning as the supplement of in-class teaching. For example, the humanistic atmosphere can be further established by organizing a series of activities, like English speech, English movie appreciation, English drama, English songs contest, and so on, thus cultivating the students' humanistic spirit unconsciously.

\section{Teaching Assessment}

Teaching assessment is an important part of implementing the curriculum ideas. We should change the uniform summative assessment mode used in the past and combine the summative assessment with the formative assessment. For example, we can establish the students' learning files in order to efficiently supervise and assess how the students perform when they are studying, especially observing their in-class performance and homework performance. The assessment bodies can be the students themselves, the classmates, or the teachers according to the real situation. The final assessment result can be obtained by proper proportion. The formative assessment focuses on the learning process, which is helpful to motivate the students to take a more active part in English learning.

\section{Conclusion}

The reason why the skills are emphasized while the humanism is ignored for college English teaching is that it is influenced by pragmatism and instrumentalism. Besides, it is also because of the one-sided recognition to the language and language learning process. Nowadays, college English teaching should reflect the humanism and the harmony of the instrumental values and the humanistic values should become the goal of college English reform, making the students not only master English as the basis of communication but also know what the humanism is by applying English to the real situation.

\section{References}

Brown, H. D. (1987). Principles of language learning and teaching (2nd ed.). New Jersey: Prentice Hall, Inc..

CHENG, X. T., \& GONG, Y. F. (2005). The theoretical basis of English course standard. Course, Teaching Materials, Teaching Method, 3, 66-72.

Du, S. Z. (1999). The principle of humanism education. Education Theory and Practice, 9, 2-7.

Krashen, S. (1985). The input hypothesis: Issue and implications. London: Longman.

Maslow, A. H. (1970). Motivation and personality. New York: Harper and Row.

WANG, S. R. (2008). Implement College English Course Teaching Requirements and deepen College English Teaching Reform. China Foreign Language, 1, 4-10.

YANG, Z. (2007). Cultivate the skills and develop the intelligence-the harmonious relationship of the instrumental values and the humanistic values of foreign language teaching. Foreign Language Research, 6, 133-137.

ZHAO, H. W. (2004). The humanism and nationality of college English teaching. The Journal of the Normal College of Qingdao University, 3, 90-92. 